\title{
Aloe vera extract as a promising treatment for the quality maintenance of minimally-processed table grapes
}

\author{
Giuseppina Rosaria Antonella ALBERIO ${ }^{1}$, Giuseppe MURATORE ${ }^{1 \star}$, Fabio LICCIARDELLO ${ }^{1}$, \\ Giovanni GIARDINA ${ }^{1}$, Giovanni SPAGNA ${ }^{1}$
}

\begin{abstract}
The effect of an edible film obtained from a commercial Aloe vera extract, on the quality maintenance of minimally processed grapes belonging to three different cultivars (Sugar One, Victoria and Black Magic) was evaluated by enzymatic (PPO, PME, $\beta$-GAL), physicochemical ( $\mathrm{pH}$, acidity, $\left.{ }^{\circ} \mathrm{Brix}\right)$, and sensorial methods. All the analyzed parameters were measured in extracts obtained from minimally processed grapes packaged in ordinary atmosphere and stored at $4{ }^{\circ} \mathrm{C}$ for 15 days. Samples dipped into Aloe vera showed significant differences $(\mathrm{p} \leq 0.05)$ compared to untreated ones. The determination of such parameters and the evaluation of consumer acceptability were helpful to determine the effectiveness of the post-harvest treatment with Aloe vera for a storage period of 15 days.
\end{abstract}

Keywords: Aloe vera; packaging; PPO; shelf life; table grape.

Practical Application: The use of Aloe vera as edible film for the treatment of minimally processed fruits could be an alternative to the use of chemical, also bearing an increase of the produce nutritional properties.

\section{Introduction}

Minimally processed fruits and vegetables are a category of foods that is subjected to few operations to get them ready for consumption. In the case of minimally processed table grapes, the fundamental processes required are washing, separation from the peduncle and packaging in trays or plastic bags. Minimally processed grape represents a promising product for distribution by vending machines, in school canteens and hospital, on airplanes or for household consumption, as an alternative to the current snacks. Indeed, this product fully meets the current market trends that require more and more high-quality products, rich from the nutritional point of view, containing only natural ingredients and minimally processed. However, minimally processed products are highly perishable, in fact, the main changes are caused by enzymatic activities (Phenylalanine ammonia-lyase (E.C. 4.3.1.5, PAL); Polyphenol oxidase (EC 1.14.18.1, PPO); $\beta$-galactosidase (EC 3.2.1.23, $\beta$-GAL), Pectin methylesterase (EC 3.1.1.11, PME)) that cause browning and the loss of consistency of the berries, decay of the sensory and nutritional properties and microbiological alterations (Botrytis cinerea). Enzymatic reactions are those mostly responsible for the loss of quality: specifically, cutting of the peduncle and physical damage determine the activation of PAL, which catalyses the transformation of phenylalanine into trans cinnamic acid which, in subsequent reactions, is transformed into other phenolic compounds such as chlorogenic acid, substrate of PPO. The latter enzyme oxidizes compounds synthesized by PAL to quinones which spontaneously polymerize, giving the molecules responsible for the enzymatic browning ( Ke
\& Saltveit, 1989). Pectic enzymes take part in the softening of tissues of vegetable products. PME catalyzes the de-esterification of pectines, hydrolyzing the methoxyl groups and producing pectic and pectinic acids with high specificity for the methoxyl groups close to the non-reducing side of the polygalaturonic chain. Oxidative and pectic enzymes play a key role in the loss of freshness of minimally processed products (Mencarelli et al., 1989; Abe \& Watada, 1991; O'Connor-Shaw et al., 1994; Paull \& Chen, 1997). Many studies have been carried out to evaluate the effect of different operations and technological solution on the activity of such enzymes with the aim of inhibiting their effect and prolonging the shelf life of produces. Among the tested solutions, the use of fungicides (Zoffoli et al., 1999; Lydakis \& Aked, 2003), immersion in hot water (Fallik, 2004; Del Nobile et al., 2008), in ethanol or chlorinated water (Ahvenainen, 1996; Soliva-Fortuny \& Martin-Belloso, 2003), the use of biodegradable films (Del Nobile et al., 2008; Rojas-Graü et al., 2009). Apart from the well-known positive effects on human health (Eshun \& $\mathrm{He}$, 2004), Aloe products have the potential to be exploited in food formulations thanks to their antimicrobial and antioxidant properties, however, processing steps necessary to obtain such produces can compromise the natural qualities (Di Scala et al., 2013) and, consequently, decrease the effectiveness. The use of Aloe $v e r a$ as edible coating for the treatment of minimally processed fruits could be a possible alternative to the use of chemicals and has already been evaluated for the quality maintenance and postharvest ripening modulation of different fruits and vegetable produces, such as avocado (Maftoonazad \& Ramaswamy, 2005), 
cut apples (Lee et al., 2003), table grapes (Valverde et al., 2005; Serrano et al., 2006), sweet cherries (Alonso \& Alique, 2004; Martínez-Romero et al., 2006), nectarines (Ahmed et al., 2009; Navarro et al., 2011), raspberries (Hassanpour, 2015), tomatoes (Athmaselvi et al., 2013), and mushrooms (Mohebbi et al., 2012). Moreover, the use of Aloe as coating matrix may result in the increase of the nutritional and health-promoting properties of minimally processed fruits. The effectiveness of Aloe vera treatments on grapes may vary depending on the moment of its application, whether in the pre-harvest or post-harvest stage (Valverde et al., 2005; Serrano et al., 2006). These authors evaluated overall multiple effects of Aloe vera on different table grape cultivars (Crimson Seedless, Vitis vinifera), such as antimicrobial effect against Botrytis cinerea, ripening delay, reduction of the antioxidant activity and effect on respiration. The present work aimed at assessing the suitability of three table grapes cultivars for transformation into a minimally processed, packed product, and at evaluating the effect of post-harvest treatments with Aloe vera and $\mathrm{SO}_{2}$ emitters on grapes quality maintenance. The aim was pursued by monitoring the evolution of PPO, PME and $\beta$-GAL responsible for the main degradative reactions occurring during refrigerated storage, and the changes in some sensory, chemical and physical parameters.

\section{Materials and methods}

\subsection{Raw material}

Table grapes belonged to cultivars Sugar One, Victoria and Black Magic. Vines were cultivated on uplands in the territory of Chiaramonte Gulfi (Ragusa, Italy) characterized by sandyclay soils, and grapes were manually harvested in June, July and September, respectively. Samples were harvested at commercial ripeness, which was assessed in accordance with the minimum requirements defined by the European Regulations (EU Reg. 543/2011) (European Commission, 2011).

\subsection{Sample processing, packaging and storage conditions}

Samples were transported by refrigerated vans and stored at $4 \pm 0.5^{\circ} \mathrm{C}$. Grapes were separated from bunches, washed in cold chlorinated water (sodium hypochlorite $2 \% \mathrm{v} / \mathrm{v}$ ), and rinsed with tap water. For each cultivar a batch of control was compared with a batch treated with a commercial Aloe vera (var. Barbadenisis Miller) extract obtained from the juice and pulp of the leaf fillet (Aloe Vera Extra, Zuccari, Trento, Italy) and one batch packed with a $\mathrm{SO}_{2}$ emitter (Productos Quimicos Alimenticios Osku SA, El Guanaco 5212/Hunchuraba-SantiagoChile, 7.0 grams) applied to the package just before sealing. Treated grapes were carefully air-dried and packed into plastic trays (Melinex 850, Pavia, Italy) containing 150 g product each, sealed with an antifog film (thickness: $35 \mu \mathrm{m}$; soldering range: $110-140^{\circ} \mathrm{C}$; water vapour permeability: $4.3 \mathrm{~g} /\left(\mathrm{m}^{2} 24 \mathrm{~h}\right)$; oxygen permeability: $1100 \mathrm{~cm}^{3} /\left(\mathrm{m}^{2} 24 \mathrm{~h}\right)$; carbon dioxide permeability: $3000 \mathrm{~cm}^{2} /\left(\mathrm{m}^{2} 24 \mathrm{~h}\right)$. Trays were stored in a refrigerated chamber at $4^{\circ} \mathrm{C}$. Analyses were performed in triplicate after 3, 6, 9, 12 and 15 days. Sensory, chemical and enzymatic analyses were performed on each batch to monitor the qualitative changes during storage.

\subsection{Headspace gas composition}

$\mathrm{O}_{2}$ and $\mathrm{CO}_{2}$ variations inside packages were monitored by a Dansensor Checkmate portable gas analyzer (PBI Dansensor, Denmark) during storage at $4^{\circ} \mathrm{C}$ on three packages for each batch at each sampling time.

\subsection{Determination of $\mathrm{pH}$, Brix degrees and acidity}

$\mathrm{pH}$ of samples was determined on the grape juice by a Gemini BV pH-meter model Inolab 720 (Gemini BV, Apeldoorn, The Netherlands), previously calibrated with buffer solutions at $\mathrm{pH} 4$ and $\mathrm{pH}$ 7. Acidity was determined by titration with $0.1 \mathrm{~N} \mathrm{NaOH}$ until $\mathrm{pH}$ 8.0, and expressed as $\mathrm{mg} / \mathrm{L}$ tartaric acid. Soluble solids were measured on filtered grape juice by a refractometer (Zeiss, mod. 16531), and expressed as Brix degrees at $20^{\circ} \mathrm{C}$.

\subsection{Enzymatic analyses}

\section{Determination of $P P O$}

To assess the activity of PPO, 10 grams of grapes are homogenized with $0.1 \mathrm{M}$ citrate-phosphate (C-P) buffer and stirred for 2 hours at $4{ }^{\circ} \mathrm{C}$. The sample was then centrifuged at $10,000 \mathrm{~g}$ for 20 minutes at $4^{\circ} \mathrm{C}$. After centrifugation, the pellet was separated from the supernatant and was vacuum filtered with Whatman filters. The raw extract was purified by ultrafiltration membranes. The test was carried out inserting $0.05 \mathrm{ml}$ of dimethylformamide, $0.05 \mathrm{M}$ of sodium acetate buffer $\mathrm{pH} 4.2$ $1.5 \mathrm{ml}, \mathrm{MBTH}$ (2\% in methanol) $0.1 \mathrm{ml}, 40 \mathrm{mM}$ catechol in $3 \mathrm{mM}$ phosphoric acid and the enzyme $0.5 \mathrm{ml}$. The reaction was stopped with $\mathrm{H} 2 \mathrm{SO} 4$ to $8 \%$ and was determined by spectrophotometric readings at $505 \mathrm{~nm}$ at $20^{\circ} \mathrm{C}$. This method is in agreement with Espín et al. (1996) suitably adapted.

\section{Determination of PME}

To evaluate the performance of PME, 10 grams of grapes are homogenized with $40 \mathrm{ml}$ of $0.2 \mathrm{M}$ citrate-phosphate (C-P) buffer at $\mathrm{pH} 7.0,1 \mathrm{M} \mathrm{NaCl}, 1 \mathrm{mM}$ dl-dithiothreitol (DTT). This sample preparation was homogenized for 2 hours at $4^{\circ}$, then centrifuged at $4{ }^{\circ} \mathrm{C}$ for 10 minutes, filtered and ultrafiltrates with a cut-off of $10 \mathrm{kDa}$ (Millipore, Bedford, MA, USA). The assay was performed by inserting $2 \mathrm{ml}$ of $0.6 \%$ apple pectin in citratephosphate (C-P) $0.05 \mathrm{M}$ buffer at $\mathrm{pH} 3.6,0.5 \mathrm{ml}$ of the previous solution extracted continuously stirred in a water thermostatized bath at $20 \pm 0.5^{\circ} \mathrm{C}$. The reaction is stopped by using $0.5 \mathrm{ml}$ of $\mathrm{H}_{2} \mathrm{SO}_{4} 1 \mathrm{~N}$. From each of these solutions was determined the methanol, produced by PE agent on pectin. The solution was brought to volume and read spectrophotometrically at $620 \mathrm{~nm}$.

\section{Determination of $\beta$-GAL}

To assess $\beta$-GAL activity, $10 \mathrm{~g}$ of homogenised grape was used along with $40 \mathrm{ml}$ of $0.2 \mathrm{M}$ citrate-phosphate (C-P) buffer at pH 4, $1 \mathrm{M} \mathrm{NaCl}$ and $1 \mathrm{mM} \mathrm{DL}$-dithiothreitol (DTT). Each of these mixtures was homogenised for $2 \mathrm{~h}$ at $40{ }^{\circ} \mathrm{C}$, centrifuged at $4000 \mathrm{~g}$ for $10 \mathrm{~min}$, filtered and ultrafiltered with a cutoff of $50 \mathrm{kDa}$ (Biomax Pellicon, Millipore Headquarters, Billerica, MA, USA). The $\beta$-GAL activity of the extract was evaluated by 
determining the amount of p-nitrophenol released from the corresponding substrate, $\mathrm{p}$-nitrophenol- $\beta$-D-galactopyranoside (Sigma-Aldrich, Milan, Italy). The assay reagents included $0.55 \mathrm{ml}$ of substrate $0.0055 \mathrm{M}, 10 \mathrm{ml}$ of C-P buffer $0.1 \mathrm{M}$ at pH 4 , and $0.30 \mathrm{ml}$ of enzyme extract. After $30 \mathrm{~min}$ at $30^{\circ} \mathrm{C}$, the reaction was stopped by adding $1 \mathrm{ml}$ of $1 \mathrm{M} \mathrm{Na}_{2} \mathrm{CO}_{3}$. The free p-nitrophenol was measured at $400 \mathrm{~nm}$ and activities were assessed in relation to the internal standard, p-nitrophenol. All tests were performed in triplicate at 95\% confidence. Protein concentration was determined according to the dye-binding method of Bradford (1976), with bovine serum albumin as the standard.

\subsection{Sensory analysis}

Sensory analysis was conducted by a panel of 10 trained assessors, according to the Quality Index method suggested by López-Gálvez et al. (1997). Samples were submitted to visual evaluation by the panelists immediately after opening the packages. A numerical scale from 1 (very low) to 9 (maximum) was used to measure the following parameters: general appearance and browning.

\subsection{Statistical analysis}

Statistical analysis was performed by SPSS Statistics 13.0 (Armonk, NY, USA) One-way analysis of variance (ANOVA) followed by post-hoc comparison of means based on the Tukey test was used to explore the significant differences among storage times. A 5\% significance level was used for all statistical comparisons.

\section{Results and discussion}

\subsection{Enzyme activities}

The enzymatic activities (PPO, PME and $\beta$-GAL) of table grapes (cv. Sugar One, Victoria, Black Magic) were characterized in the fresh product (Figures 1a-c). The three cultivars analyzed showed comparable initial values of PPO activity, with slightly higher values for the cultivar Victoria. In addition, the three cultivars showed significant differences in the activity of PME and $\beta$-GAL with values of enzyme activity decreasing in the order: Black Magic $>$ Sugar One > Victoria. Such enzymatic parameters were related respectively with general appearance and degree of gilding of the grapes for a period of cold storage of 15 days. Figures $2 \mathrm{a}-\mathrm{c}$, respectively, show the total enzymatic activity (PPO, PME and $\beta$-GAL) during storage time for minimally processed grapes in response to the different treatments, i.e. dipping in Aloe vera and packaging with $\mathrm{SO}_{2}$ emitters. According to Figure 2a, the untreated cultivar Sugar One was characterized by the highest total PPO activity, while the cultivar Victoria presented the lowest enzymatic activity. Treatment with Aloe vera significantly reduced $(\mathrm{p} \leq 0.05)$ the enzymatic activity of PPO only in cultivar Sugar One, despite presented the highest total polyphenoloxidase activity without any treatment compared to other cultivars. Regarding PME (Figure 2b), untreated Sugar One and Victoria cultivars showed high values of total activity comparable during cold storage, while the Black Magic was characterized by a lower PME activity. Treatment with Aloe vera was ineffective at inhibiting PME in all three cultivars, even in the case of the cultivar Black Magic it resulted in a significant increase $(\mathrm{p} \leq 0.05)$ of PME activity. As can be inferred from Figure 2c, the untreated cultivar Victoria showed the highest total $\beta$-GAL activity, while Sugar One and Black Magic showed comparable activity. Treatment with Aloe vera significantly reduced activity of $\beta$-GAL $(\mathrm{p} \leq 0.05)$ in the cultivars Black Magic and Victoria. Valverde et al. (2005) hypothesized some role of Aloe vera gel in the reduction of the activity of $\beta$-galactosidase, polygalacturonase and pectinmethylesteras, which are considered as the main cell wall degrading enzymes responsible for table grape softening (Nunan et al., 1998). Our study confirms this hypothesis, even if the effectiveness of Aloe seems to be cultivar-dependant. Further research is needed in order to understand the mechanism of action and the reasons for its selective effectiveness.

Overall, the treatment with Aloe vera was effective in all tested cultivars, in particular for the inhibition of PPO and PME, mainly responsible for the process of browning and softening of grapes. The effectiveness of Aloe vera in minimally processed fruit had been demonstrated using different fruits such as the pomegranate and sweet cherries (Ahmed et al.,
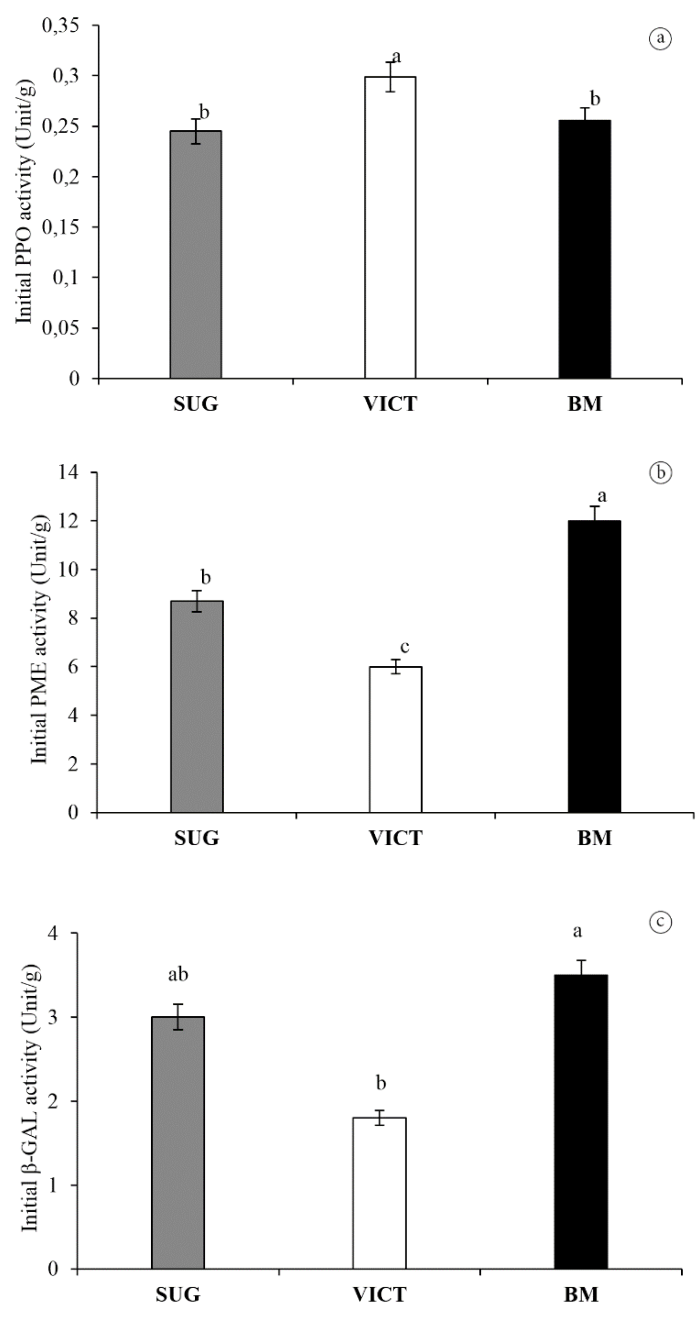

Figure 1. Initial PPO (a), PME (b) and $\beta$-GAL (c) activities in Sugar One (SUG), Victoria (VICT) and Black Magic (BM) table grape cultivars. Different letters indicate significant differences $(\mathrm{P} \leq 0.05)$ among cultivars. 

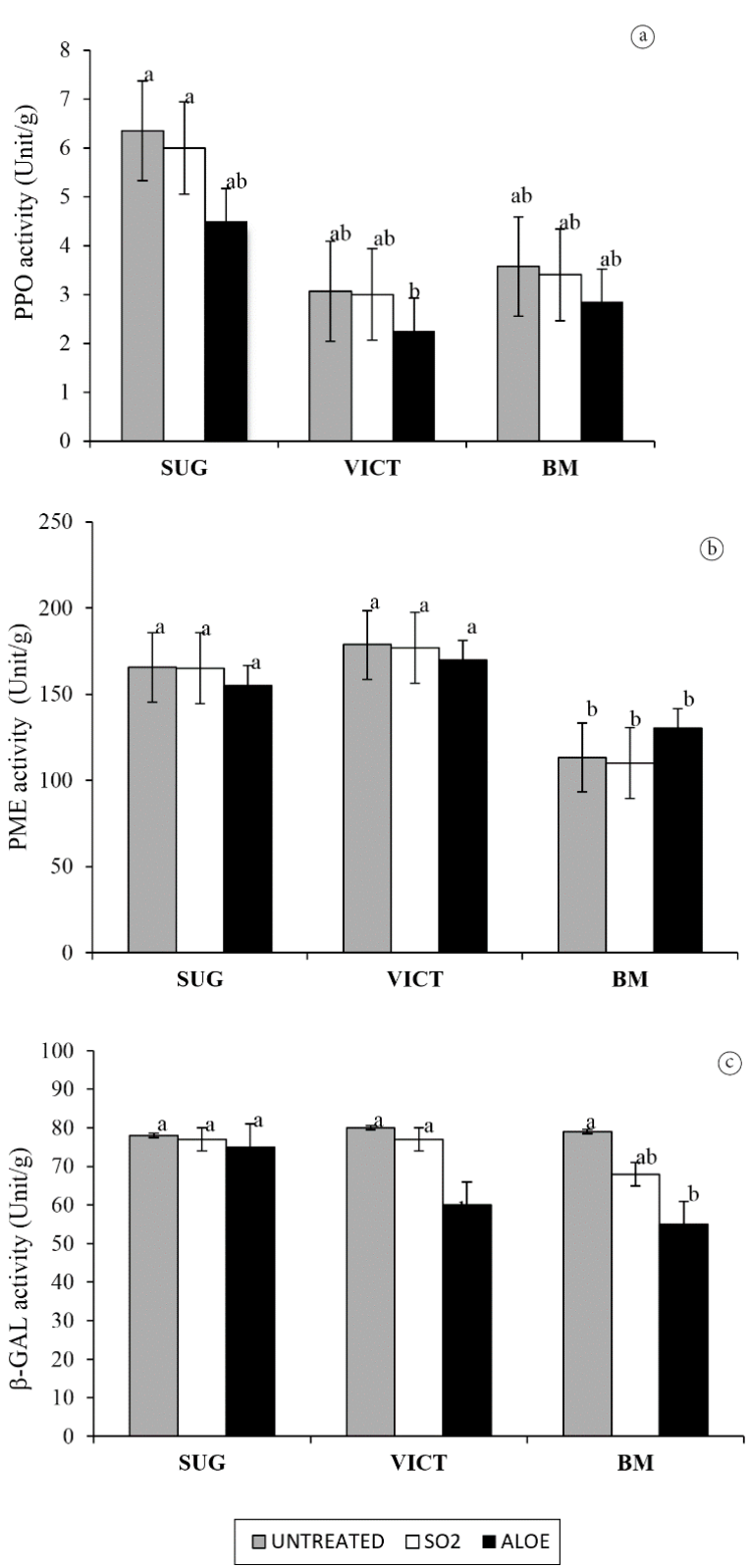

Figure 2. PPO (a), PME (b) and $\beta-G A L$ (c) total activities during refrigerated storage for Sugar One (SUG), Victoria (VICT) and Black Magic (BM) table grape cultivars. $\square$ : untreated; $\square$ : $\mathrm{SO}_{2}$ emitter; Aloe-based dipping. Different letters indicate significant differences $(\mathrm{P} \leq 0.05)$ among cultivars.

2009; Conte et al., 2009). The addition of $\mathrm{SO}_{2}$ emitters of as an alternative to the dipping did not give any advantage in terms of enzyme inhibition. Furthermore, the cultivar that, from the enzymatic standpoint, was found to be most suitable for minimal processing, was Black Magic.

\subsection{Headspace gas composition}

The gas composition inside packages of treated and control table grapes, which is a measure of the produce respiration extent, changed significantly particularly during the second week of refrigerated storage. Figures $3 \mathrm{a}$-c showed the increment of $\mathrm{CO}_{2}$ and decrease of $\mathrm{O}_{2}$ as a consequence of the respiration of the produce. The treatment with Aloe vera seems to reduce respiration in the Victoria and Black Magic cultivars, so that the $\mathrm{CO}_{2}$ level after 15 days of storage did not exceed $25 \%$, contrarily to untreated and $\mathrm{SO}_{2}$-treated samples, and to Sugar One samples, irrespective of the treatment, for which the $\mathrm{CO}_{2}$ level reached values as high as $35 \%$. Studies in literature have led to controvertial results on the effect of modified and ordinary atmosphere for the preservation of fruits and vegetables (Siriphanick \& Kader, 1985). The dipping with Aloe vera was effective at slowing down the production of $\mathrm{CO}_{2}$ and depletion of $\mathrm{O}_{2}$ in Victoria and Black Magic cultivars, this result is in agreement with a previous study (Valverde et al., 2005). The reduction of respiration determined by the application of coatings has been observed in various fruits, such as avocado (Maftoonazad \& Ramaswamy, 2005), cut apples (Lee et al., 2003), table grapes (Valverde et al., 2005) and sweet cherry (Alonso \& Alique, 2004; Martinez-Romero et al., 2006), and is due to the partial barrier to gas exchange which, in turn, allows the creation of an internal modified atmosphere (Banks et al., 1993). On the other hand, the respiration of the Sugar One cultivar was slightly reduced by the $\mathrm{SO}_{2}$ treatment, which was ineffective on the other two cultivars.

\subsection{Physicochemical parameters}

The physicochemical features and statistical significance of differences among means are shown in Table 1. In particular, $\mathrm{pH}$, acidity and ${ }^{\circ}$ Brix were monitored during 15 days of refrigerated storage. All untreated samples were characterized by a $\mathrm{pH}$ around 3.5 , and mean values did not differ significantly $(\mathrm{p} \leq 0.05)$ in the fresh produce, irrespective of the cultivar. The addition of Aloe vera did not determine significant $\mathrm{pH}$ differences in any of the cultivars during storage, as well as the use of $\mathrm{SO}_{2}$ emitters. Acidity did not vary significantly among cultivars, and showed only a slight reduction during refrigerated storage.

Table 1 also shows the ${ }^{\circ}$ Brix values during refrigerated storage. The value in the fresh produce was significantly lower for the Victoria cultivar (around 10\%) compared to Sugar One and Black Magic varieties, which had a soluble solids content around $13 \%$. The ${ }^{\circ}$ Brix did not vary significantly during refrigerated storage with any of the treatments used.

\subsection{Sensory analysis}

At the beginning of the experiment all batches from each minimally processed table grape cultivars, irrespective of treatment, showed high overall quality scores (Figure 4). In particular, during the first week of storage the berries presented an extremely shiny, clearly defined color, without traces of browning in the zone of the petiole. This could be due to the fact that grapes were not cut and minimal damage was caused to the fruits before packaging. Indeed, browning, senescence and the increase of respiration rate depend on the extent of damage and cell ruptures (Böttcher et al., 2003; Del Nobile et al., 2007). In other fruit varieties such as mango, banana, strawberries and water melon, cutting accelerated the browning processes (Cocci et al., 2006). According to a study by Ke \& Saltveit (1989), the PAL activity is stimulated by cutting much more than by ethylene (Spagna et al., 2005). Samples packed with $\mathrm{SO}_{2}$ 

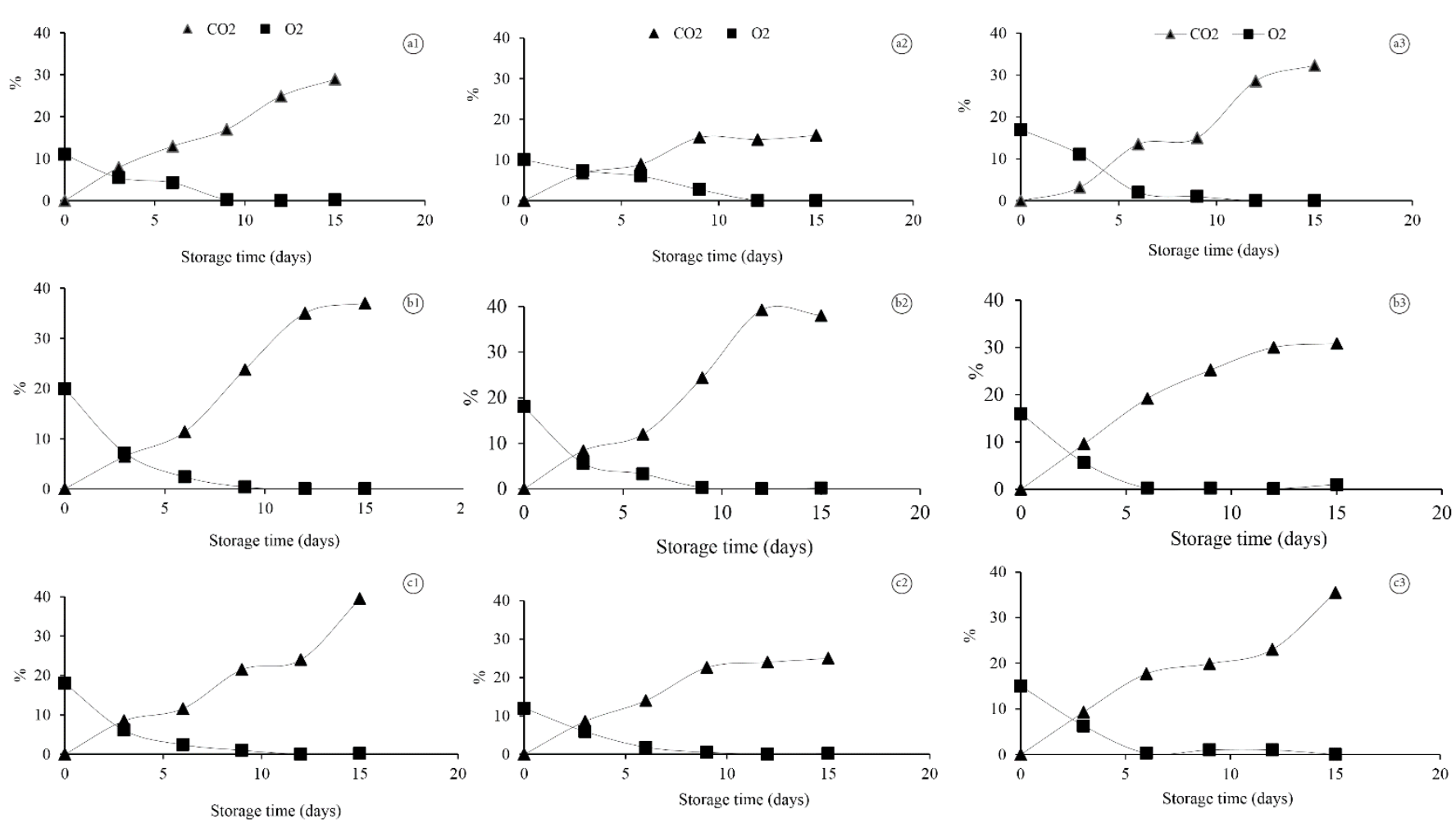

Figure 3. Gas evolution $\left(\mathrm{O}_{2}, \mathrm{CO}_{2}\right)$ inside the packaging during cold storage for Victoria (figures a), Sugar One (figures b) and Black Magic (figures c). 1: no treatment; 2: Aloe-based dipping; 3: treatment with $\mathrm{SO}_{2}$.

Table 1. Ph ${ }^{\circ}$ BRIX and acidity of Sugar One (SUG). Black Magic (BM) and Victoria (VICT) table grape cultivars during refrigerated storage. as a function of treatment.

\begin{tabular}{|c|c|c|c|c|c|c|c|c|c|c|c|c|c|c|c|c|c|c|}
\hline \multirow{2}{*}{$\begin{array}{l}\text { Time } \\
\text { (days) }\end{array}$} & \multicolumn{6}{|c|}{$\mathrm{pH}$} & \multicolumn{6}{|c|}{${ }^{\circ}$ Brix } & \multicolumn{6}{|c|}{ Acidity $(\mathrm{mg} / \mathrm{L})$} \\
\hline & 0 & 3 & 6 & 9 & 12 & 15 & 0 & 3 & 6 & 9 & 12 & 15 & 0 & 3 & 6 & 9 & 12 & 15 \\
\hline SUG & 3.67 & 3.76 & $3.566^{\mathrm{ab}}$ & $3.73^{b}$ & $3.73^{b}$ & $3.70^{\mathrm{b}}$ & $11.93^{b c}$ & $12.13^{b}$ & $12.00^{b}$ & $12.07^{b}$ & $12.03^{\mathrm{abc}}$ & $11.97^{b c}$ & $1.20_{\mathrm{A}}$ & $1.90_{\mathrm{B}}$ & $1.97_{\mathrm{B}}^{\mathrm{b}}$ & $2.07_{B}^{c}$ & $2.00_{B}^{c}$ & $2.00_{\mathrm{B}}^{\mathrm{b}}$ \\
\hline $\begin{array}{l}\text { SUG } \\
\text { Aloe }\end{array}$ & 3.60 & 3.60 & $3.67^{\mathrm{ab}}$ & $3.75^{\mathrm{b}}$ & $3.73^{\mathrm{b}}$ & $3.50^{\mathrm{ab}}$ & $13.93^{\mathrm{d}}$ & $13.97^{\mathrm{cd}}$ & $13.96^{c}$ & $13.93^{\mathrm{c}}$ & $13.90^{\mathrm{cd}}$ & $13.97^{\mathrm{d}}$ & $1.52_{\text {в }}$ & $1.53_{\mathrm{B}}$ & $1.07{ }_{\mathrm{A}}^{\mathrm{a}}$ & $1.000_{\mathrm{A}}^{\mathrm{a}}$ & $1.07_{\mathrm{A}}^{\mathrm{ab}}$ & $1.03_{\mathrm{A}}^{\mathrm{ab}}$ \\
\hline $\mathrm{SUG} \mathrm{SO}_{2}$ & 3.53 & 3.73 & $3.30^{\mathrm{ab}}$ & $3.03^{\mathrm{a}}$ & $3.20^{\mathrm{a}}$ & $3.07^{\mathrm{a}}$ & $13.87^{\mathrm{d}}$ & $13.97^{\mathrm{cd}}$ & $13.83^{\mathrm{c}}$ & $13.97^{\mathrm{c}}$ & $13.90^{\mathrm{cd}}$ & $14.07^{\mathrm{d}}$ & 1.33 & 1.40 & $1.10^{\mathrm{a}}$ & $1.03^{\mathrm{a}}$ & $1.07^{\mathrm{ab}}$ & $1.00^{\mathrm{a}}$ \\
\hline $\mathrm{BM}$ & 3.62 в & $3.53_{\text {в }}$ & $2.9^{\mathrm{a}}{ }_{\mathrm{A}}$ & $3.63^{\mathrm{ab}}$ & $3.90^{\mathrm{b}}$ & $3.73_{\mathrm{B}}^{\mathrm{b}}$ & $11.97^{b c}$ & $11.97^{b}$ & $11.93^{b}$ & $11.77^{b}$ & $11.82^{\mathrm{ab}}$ & $12.40^{c}$ & $1.40_{\mathrm{AB}}$ & $1.47_{\mathrm{AB}}$ & $1.00_{\mathrm{A}}^{\mathrm{a}}$ & $1.93_{\mathrm{B}}^{\mathrm{c}}$ & $1.03^{\mathrm{a}}{ }_{\mathrm{A}}$ & $1.33_{\mathrm{AB}}^{\mathrm{ab}}$ \\
\hline VICT & 3.50 & 3.52 & $3.43^{\mathrm{ab}}$ & $3.60^{\mathrm{ab}}$ & $3.63^{\mathrm{ab}}$ & $3.63^{\mathrm{ab}}$ & $10.27^{\mathrm{a}}$ & $9.93^{\mathrm{a}}$ & $10.00^{\mathrm{a}}$ & $10.50^{\mathrm{a}}$ & $10.67^{\mathrm{a}}$ & $10.33^{\mathrm{a}}$ & 1.33 & 1.40 & $1.10^{\mathrm{a}}$ & $1.03^{\mathrm{a}}$ & $1.07^{\mathrm{ab}}$ & $1.00^{\mathrm{a}}$ \\
\hline $\begin{array}{l}\text { VICT } \\
\text { Aloe }\end{array}$ & 3.53 & 3.53 & $3.45^{\mathrm{ab}}$ & $3.50^{\mathrm{ab}}$ & $3.52^{\mathrm{ab}}$ & $3.50^{\mathrm{ab}}$ & $10.67^{\mathrm{ab}}$ & $11.67^{b}$ & $11.33^{b}$ & $11.63^{b}$ & $11.33^{\mathrm{ab}}$ & $11.00^{\mathrm{ab}}$ & $1.40_{\mathrm{AB}}$ & $1.47_{\mathrm{AB}}$ & $1.00_{\mathrm{A}}^{\mathrm{a}}$ & $1.93_{\mathrm{B}}^{\mathrm{c}}$ & $1.03_{\mathrm{A}}^{\mathrm{a}}$ & $1.33_{\mathrm{AB}}^{\mathrm{ab}}$ \\
\hline $\begin{array}{l}\text { VICT } \\
\mathrm{SO}_{2}\end{array}$ & 3.52 & 3.47 & $3.53^{\mathrm{ab}}$ & $3.47^{\mathrm{ab}}$ & $3.93^{\mathrm{b}}$ & $3.97^{\mathrm{b}}$ & $12.33^{c}$ & $11.97^{\mathrm{b}}$ & $12.27^{b}$ & $12.00^{\mathrm{b}}$ & $11.87^{\mathrm{ab}}$ & $12.33^{\mathrm{c}}$ & 1.57 & 1.50 & $1.23^{\mathrm{a}}$ & $1.50^{\mathrm{b}}$ & $1.30^{\mathrm{b}}$ & $1.20^{\mathrm{ab}}$ \\
\hline
\end{tabular}

Different small letters in columns indicate significant difference $(\mathrm{P} \leq 0.05)$ among average values relative to different treatments. Different capital letters in lines indicate significant difference $(\mathrm{P} \leq 0.05)$ among average values relative to different storage times.

emitters did not show significative differences compared with the untreated samples.

Treatment with Aloe vera was found to be more effective in its first week on the cultivar Black Magic, while from the second week this treatment was found to be ineffective.

Figure 5 shows that all samples maintained low browning scores until 6 days of storage, afterwards some signs of alteration appeared, with special regards for the zone of the insertion of the petiole, as consequence of the petiole removal. Aloe-based treatment was able to maintain the general visual quality of Sugar One and Victoria by significantly reducing browning (Figures $5 \mathrm{a}, \mathrm{b}$ ). This effect confirms a protective effect of Aloe, which has been previously demonstrated and is to be mainly attributed to the antioxidant capacity of its components $(\mathrm{Hu}$ et al., 2005). 

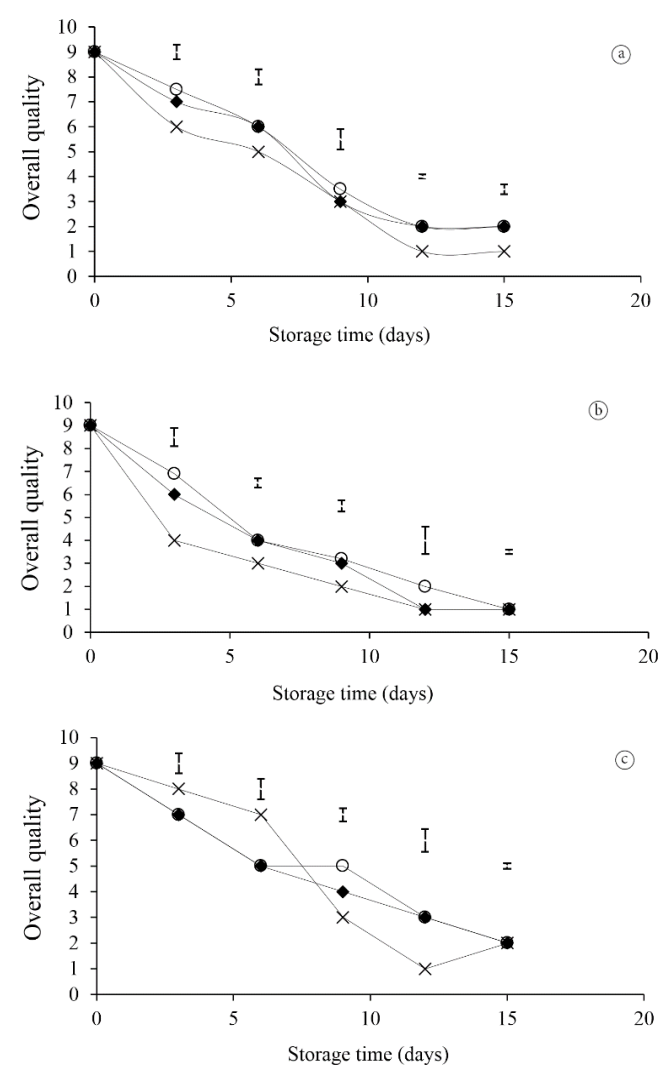

$\leftarrow$ Untreated $\multimap \mathrm{SO}_{2} \quad *$ Aloe

Figure 4. Overall quality for Sugar One (a), Victoria (b) and Black Magic (c) table grape cultivars as a function of treatment: $\bullet-$ untreated; -0 SO2 emitter; $*$ Aloe-based dipping. Vertical bars indicate the least significant difference (multiple range test, $P \leq 0.05$ ).

\section{Conclusions}

Results point out some differences in the response of three table grape cultivars to minimal processing. Dipping into an Aloe vera extract allowed to reduce the respiration rate of Victoria and Black Magic cultivars and was effective at reducing the enzymatic activities commonly considered as responsible for the quality decay. Also, the general aspect and browning extent confirmed the ability of table grapes coating with Aloe vera to maintain better scores for at least 6 days compared to untreated table grapes. Dipping into Aloe vera represents a natural tool for the quality maintenance of minimally processed table grapes, improving the produce nutritional value and allowing to reduce the recourse to synthetic additives.

\section{References}

Abe, K., \& Watada, A. E. (1991). Ethyene absorbent to maintain quality of lightly processed fruits and vegetables. Journal of Food Science, 56(6), 1493-1496.

Ahmed, M. J., Singh, Z., \& Khan, A. S. (2009). Postharvest Aloe vera gel-coating modulates fruit ripening and quality of 'Arctic Snow' nectarine kept in ambient and cold storage. International Journal
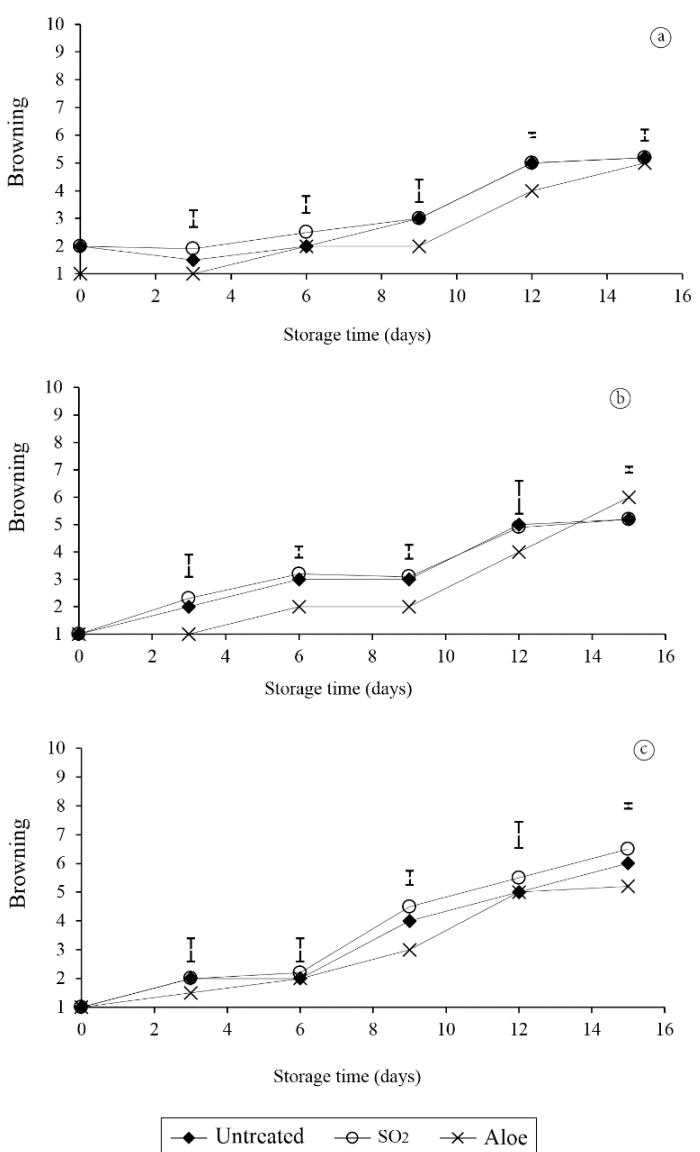

Figure 5. Browning degree of Sugar One (a), Victoria (b) and Black Magic (c) table grape cultivars as a function of treatment: $\bullet$ untreated; - SO2 emitter; $\leftarrow$ Aloe-based dipping. Vertical bars indicate the least significant difference (multiple range test, $P \leq 0.05$ ).

of Food Science \& Technology, 44(5), 1024-1033. http://dx.doi. org/10.1111/j.1365-2621.2008.01873.x.

Ahvenainen, R. (1996). New approaches in improving the shelf life of minimally processed fruit and vegetables. Trends in Food Science \& Technology, 7(6), 179-187. http://dx.doi.org/10.1016/09242244(96)10022-4.

Alonso, J., \& Alique, R. (2004). Influence of edible coating on shelf life and quality of "Picota" sweet cherries. European Food Research and Technology, 218(6), 535-539. http://dx.doi.org/10.1007/s00217004-0908-3.

Athmaselvi, K. A., Sumitha, P., \& Revathy, B. (2013). Development of Aloe vera based edible coating for tomato. International Agrophysics, 27(4), 369-375.

Banks, N. H., Dadzie, B. K., \& Cleland, D. J. (1993). Reducing gas exchange of fruits with surface coating. Postharvest Biology and Technology, 3(3), 269-284. http://dx.doi.org/10.1016/0925-5214(93)90062-8.

Böttcher, H., Günther, I., \& Kabelitz, L. (2003). Physiological postharvest responses of Common Saint-John's wort herbs (Hypericum perforatum L.). Postharvest Biology and Technology, 29(3), 343-351. http://dx.doi. org/10.1016/S0925-5214(03)00057-7.

Bradford, M. M. (1976). A rapid and sensitive method for the quantitation of microgram quantities of protein utilizing the principle of protein- 
dye binding. Analytical Biochemistry, 72(1-2), 248-254. http://dx.doi. org/10.1016/0003-2697(76)90527-3. PMid:942051

Cocci, E., Rocculi, P., Romani, S., \& Dalla Rosa, M. (2006). Changes in nutritional properties of minimally processed apples during storage. Postharvest Biology and Technology, 39(3), 265-271. http://dx.doi. org/10.1016/j.postharvbio.2005.12.001.

Conte, A., Scrocco, C., Lecce, L., Mastromatteo, M., \& Del Nobile, M. A. (2009). Ready-to-eat sweet cherries: study on different packaging systems. Innovative Food Science \& Emerging Technologies, 10(4), 564-571. http://dx.doi.org/10.1016/j.ifset.2008.12.005.

Del Nobile, M. A., Licciardello, F., Scrocco, C., Muratore, G., \& Zappa, M. (2007). Design of plastic packages for minimally processed fruits. Journal of Food Engineering, 79(1), 217-224. http://dx.doi. org/10.1016/j.jfoodeng.2006.01.062.

Del Nobile, M. A., Sinigaglia, M., Conte, A., Speranza, B., Scrocco, C., Brescia, I., Bevilacqua, A., Laverse, J., La Notte, E., \& Antonacci, D. (2008). Influence of postharvest treatments and film permeability on quality decay kinetics of minimally processed grapes. Postharvest Biology and Technology, 47(3), 389-396. http://dx.doi.org/10.1016/j. postharvbio.2007.07.004.

Di Scala, K., Vega-Gálvez, A., Ah-Hen, K., Nuñez-Mancilla, Y., TabiloMunizaga, G., Pérez-Won, M., \& Giovagnoli, C. (2013). Chemical and physical properties of aloe vera (Aloe barbadensis Miller) gel stored after high hydrostatic pressure processing. Food Science and Technology, 33(1), 52-59.

Eshun, K., \& He, Q. (2004). Aloe vera: a valuable ingredient for the food, pharmaceutical and cosmetic industries-a review. Critical Reviews in Food Science and Nutrition, 44(2), 91-96. http://dx.doi. org/10.1080/10408690490424694. PMid:15116756

Espín, J. C., Morales, M., Varon, R., Tudela, J., \& García-Cánovas, F. (1996). Continuous spectrophotometric method for determing Monophenolase and Diphenolase activities of Pear Polyphenolxidase. Journal of Food Science, 61(6), 1177-1182. http://dx.doi.org/10.1111/j.1365-2621.1996. tb10955.x.

European Commission. (2011). Commission Implementing Regulation (EU) No. 543/2011 of 7 June 2011: laying down detailed rules for the application of Council Regulation (EC) No 1234/2007 in respect of the fruit and vegetables and processed fruit and vegetables sectors. Annex 1, part B9.

Fallik, E. (2004). Prestorage hot water treatments (immersion, rinsing and brushing). Postharvest Biology and Technology, 32(2), 125-134. http://dx.doi.org/10.1016/j.postharvbio.2003.10.005.

Hassanpour, H. (2015). Effect of Aloe vera gel coating on antioxidant capacity, antioxidant enzyme activities and decay in raspberry fruit. LWT - Food Science and Technology, 60(1), 495-501. http://dx.doi. org/10.1016/j.lwt.2014.07.049.

Hu, Q., Hu, Y., \& Xu, J. (2005). Free radical-scavenging activity of Aloe Vera (Aloe barbadensis Miller) extracts by supercritical carbon dioxide extraction. Food Chemistry, 91(1), 85-90. http://dx.doi. org/10.1016/j.foodchem.2004.05.052.

Ke, D., \& Saltveit, M. E. Jr. (1989). Wound-induced ethylene production, phenolic metabolism and susceptibility to russet spotting in iceberg lettuce. Plant Physiology, 76(3), 412-418. http://dx.doi. org/10.1111/j.1399-3054.1989.tb06212.x.

Lee, J. Y., Park, H. J., Lee, C. Y., \& Choi, W. Y. (2003). Extending shelflife of minimally processed apples with edible coatings and antibrowning agents. LWT - Food Science and Technology, 36(3), 323-329. http:// dx.doi.org/10.1016/S0023-6438(03)00014-8.

López-Gálvez, G., Peiser, G., Nie, X., \& Cantwell, M. (1997). Quality changes in packaged salad products during storage. Zeitschrift fur
Lebensmittel-Untersuchung und -Forschung, 205(1), 64-72. http:// dx.doi.org/10.1007/s002170050125.

Lydakis, D., \& Aked, J. (2003). Vapour heat treatment of Sultanina table grapes. I. Control of Botrytis cinerea. Postharvest Biology and Technology, 27(2), 109-116. http://dx.doi.org/10.1016/S09255214(02)00091-1.

Maftoonazad, N., \& Ramaswamy, H. S. (2005). Postharvest shelflife extension of avocados using methyl cellulose-based coating. LWT - Food Science and Technology, 38(6), 617-624. http://dx.doi. org/10.1016/j.lwt.2004.08.007.

Martínez-Romero, D., Alburquerque, N., Valverde, J. M., Guillén, F., Castillo, S., Valero, D., \& Serrano, M. (2006). Postharvest sweet cherry quality and safety maintenance by Aloe vera treatment: a new edible coating. Postharvest Biology and Technology, 39(1), 93-100. http://dx.doi.org/10.1016/j.postharvbio.2005.09.006.

Mencarelli, F., Saltveit, M. E. J., \& Massantini, R. (1989). Lightly processed foods: ripening of tomato fruit slices. Acta Horticulturae, 244, 193-200.

Mohebbi, M., Ansarifar, E., Hasanpour, N., \& Amiryousefi, M. R. (2012). Suitability of Aloe vera and gum tragacanth as edible coatings for extending the shelf life of button mushroom. Food Bioprocess Technology, 5(8), 3193-3202. http://dx.doi.org/10.1007/ s11947-011-0709-1.

Navarro, D., Díaz-Mula, H. M., Guillén, F., Zapata, P. J., Castillo, S., Serrano, M., Valero, D., \& Martínez-Romero, D. (2011). Reduction of nectarine decay caused by Rhizopus stolonifer, Botrytis cinerea and Penicillium digitatum with Aloe vera gel alone or with the addition of thymol. International Journal of Food Microbiology, 151(2), 241-246. http://dx.doi.org/10.1016/j.ijfoodmicro.2011.09.009. PMid:21974979

Nunan, K. J., Sims, I. M., Bacic, A., Robinson, S. P., \& Fincher, G. B. (1998). Changes in cell wall composition during ripening of grape berries. Plant Physiology, 118(3), 783-792. http://dx.doi.org/10.1104/ pp.118.3.783. PMid:9808722

O'Connor-Shaw, R. E., Roberts, R., Ford, A. L., \& Nottingham, S. M. (1994). Shelf-life of minimally processed honeydew, kiwifruit, papaya, pineapple and cantaloupe. Journal of Food Science, 59(6), 1202-1206. http://dx.doi.org/10.1111/j.1365-2621.1994.tb14676.x.

Paull, R. E., \& Chen, W. (1997). Minimal processing of papaya (Carica papaya L.) and the physiology of halved fruit. Postharvest Biology and Technology, 12(1), 93-99. http://dx.doi.org/10.1016/S09255214(97)00030-6.

Rojas-Graü, M. A., Soliva-Fortuny, R., \& Martín-Belloso, O. (2009). Edible coatings to incorporate active ingredients to fresh-cut fruits: a review. Trends in Food Science \& Technology, 20(10), 438-447. http://dx.doi.org/10.1016/j.tifs.2009.05.002.

Serrano, M., Valverde, J. M., Guillén, F., Castillo, S., Martínez-Romero, D., \& Valero, D. (2006). Use of Aloe vera gel coating preserves the functional properties of table grapes. Journal of Agricultural and Food Chemistry, 54(11), 3882-3886. http://dx.doi.org/10.1021/ jf060168p. PMid:16719510

Siriphanich, J., \& Kader, A. A. (1985). Effects of CO2 on total phenolics, phenylalanine ammonia lyase, and polyphenol oxidase in lettuce tissue. Journal of the American Society for Horticultural Science, 110(2), 249-253.

Soliva-Fortuny, R. C., \& Martin-Belloso, O. (2003). New advances in extending the shelf-life of fresh-cut fruit: a review. Trends in Food Science \& Technology, 14(9), 341-353. http://dx.doi.org/10.1016/ S0924-2244(03)00054-2.

Spagna, G., Barbagallo, R. N., Chisari, M., \& Branca, F. (2005). Characterization of a tomato polyphenol oxidase and its role in 
browning and lycopene content. Journal of Agricultural and Food Chemistry, 53(6), 2032-2038. http://dx.doi.org/10.1021/jf040336i. PMid:15769132

Valverde, J. M., Valero, D., Martínez-Romero, D., Guillén, F., Castillo, S., \& Serrano, M. (2005). Novel edible coating based on aloe vera gel to maintain table grape quality and safety. Journal of Agricultural and Food Chemistry, 53(20), 7807-7813. http://dx.doi.org/10.1021/ jf050962v. PMid:16190634

Zoffoli, J. P., Latorre, B. A., Rodrìguez, E. J., \& Aldunce, P. (1999). Modified atmosphere packaging using chlorine gas generators to prevent Botrytis cinerea on table grapes. Postharvest Biology and Technology, 15(2), 135-142. http://dx.doi.org/10.1016/S0925-5214(98)00078-7. 